\title{
THE ROLE OF FAMILY SUPPORT IN THE PREVENTION OF DRUG ABUSE AMONG ADOLESCENTS IN SIMALUNGUN, NORTH SUMATERA
}

\author{
Venni Yuasnita Damanik
}

Masters Program in Public Health, Universitas Sumatera Utara

\begin{abstract}
Background: Family is the single most important influence in a child's life. From their first moments of life, children depend on parents and family to protect them and provide for their needs. This study aimed to examine the role of family support in the prevention of drug abuse among adolescents in Simalungun, North Sumatera.

Subjects and Method: This was a cross-sectional study conducted in Simalungun, North Sumatera. A total of 61 high school students were selected for this study. The dependent variable was prevention of drug abuse. The independent variable was family support. The data were collected by questionnaire and analyzed by a logistic regression.

Results: Prevention of drug abuse was associated with strong family support $(\mathrm{OR}=3.75 ; \mathrm{p}=0.007)$.

Conclusion: Strong family support is associated with prevention of drug abuse among adolescents.
\end{abstract}

Keywords: drug abuse, family support, adolescent.

\section{Correspondence:}

Venni Yuasnita Damanik. Masters Program in Public Health, Universitas Sumatera Utara. Email: vennidamanik@gmail.com. Mobile: 085275985572 